\title{
Artificial environmental radionuclides in Europe and methods of lowering their foodstuff contamination - a review
}

\author{
Katarína Beňová1, Petr Dvořák ${ }^{2}$, Martin Tomko ${ }^{1}$, Marcel Falis ${ }^{3}$ \\ ${ }^{1}$ University of Veterinary Medicine and Pharmacy, Department of Biology and Genetics, \\ Kosice, Slovak Republic \\ ${ }^{2}$ University of Veterinary and Pharmaceutical Sciences Brno, Faculty of Veterinary Hygiene and Ecology, \\ Department of Biochemistry and Biophysics, Brno, Czech Republic \\ ${ }^{3}$ University of Veterinary Medicine and Pharmacy, Department of Pharmacology and Toxicology, \\ Kosice, Slovak Republic
}

Received September 16, 2015

Accepted February 10, 2016

\begin{abstract}
This review discusses the consequences of the food chain contamination with radionuclides, especially focusing on the radiocaesium impact after the Chernobyl nuclear accident. In particular, the ${ }^{137} \mathrm{Cs}$ isotope still represents a risk. Until present it is still detectable in the meat of game animals, especially in wild boar, but also in elk and reindeer. Although the occurrence of highly contaminated foods in most of Europe is currently limited, along the German-Czech border (the Sumava Region) the activity concentration of the ${ }^{137} \mathrm{Cs}$ isotope in the meat of wild boar exceeds the acceptable limit several times. Additionally, the article describes simple processing technologies (cooking, pickling etc.) that lead to reduction of radionuclides in contaminated food.
\end{abstract}

Chernobyl, ${ }^{137} \mathrm{Cs}$, food safety, radiocaesium reduction, wild boar

Within the terrestrial environment of Europe, contamination by anthropogenic radionuclides comes from two different sources. The first source was the global atmospheric fallout, which appeared after the start of intensive atmospheric nuclear weapon testing in the 1950s, and has been observed for a long time after their completion in 1963.

The second source of terrestrial contamination was the fallout after the nuclear reactor accident at Chernobyl in 1986. In terms of time, it was a one-time contamination, where the intensity of radioactive fallout was determined by the local meteorological situation and movement of contaminated air masses. The Fukushima nuclear accident which contaminated mainly Japan and a significant part of Asia, only had a limited impact on Europe.

\section{Radionuclide contamination}

\section{Relevant radionuclides}

From the radio-ecological perspective, only the long-lived components of nuclear weapons testing are relevant $\left({ }^{90} \mathrm{Sr},{ }^{137} \mathrm{Cs},{ }^{238} \mathrm{Pu},{ }^{239} \mathrm{Pu}\right)$. The most important long-lived contaminant was the caesium ${ }^{137} \mathrm{Cs}$ isotope (Högberg 2013). The level of contamination in a certain area was dependent on the latitude and long-term weather situation, particularly precipitation (Csupka et al. 1978). Currently, the ${ }^{137} \mathrm{Cs}$ from this source, is already largely immobilized in the clay fraction of the soil, with limited access for plant roots (Nimis 1996).

The Chernobyl nuclear accident on April 26, 1986, caused a release of radioactive caesium at the amount up to $3.8 \times 10^{16} \mathrm{~Bq}$. The ratio of ${ }^{137} \mathrm{Cs}$ to ${ }^{134} \mathrm{Cs}$ long-lived radionuclides released was approximately 2 : 1 (UNSCEAR 1988). The radioactive cloud passed over

Address for correspondence:

Martin Tomko

Department of Biology and Genetics

University of Veterinary Medicine and Pharmacy

Komenského 73, 04181 Košice, Slovak Republic

Phone: +421918413553

E-mail: martin.tomko@uvlf.sk

http://actavet.vfu.cz/ 
the continent three times. On some territories with intensive rainfalls, increased soil contamination by large amounts of radionuclides was observed. Besides the Ukraine, Belarus and Russia, the most affected parts of Europe also included Norway, where the surface activity values reached up to $500 \mathrm{kBq} \cdot \mathrm{m}^{-2}$ (Pedersen et al. 1998).

\section{Soil contamination}

Due to the elapsed time and the nature of the Chernobyl accident, currently the only artificial radionuclide present in the soil is ${ }^{137} \mathrm{Cs}$, with a physical half-life of 30.17 years (Krolak et al. 2010). The ${ }^{137} \mathrm{Cs}$ quickly integrated into the biological cycle, similarly to potassium. Generally, radionuclides are characterized by their mobility in soil (Gadd 1996). Analysis has shown that the diffusion coefficient of radionuclides in the soil is affected by the soil moisture, presence of chemical homologs determining the capacity of the exchange process in the soil, soil acidity, soil humus content, and temperature (Koprda 1986).

High mobility of radiocaesium gradually decreased after its deposition in the soil. Differences in mobility were observed especially in the non-cultivated meadow and forest soils, and were associated with the soil depth. In mineral soils with increasing depth, the amount of ${ }^{137} \mathrm{Cs}$ accessible by plants may rise, however it depends on many factors and circumstances (Schimmack and Bunzl 1996). Tomioka et al. (1992) reported several conditions which play an important role in the maintenance of radiocaesium stability in the surface layers of forest soils especially soil bacteria.

Soil contamination by different radionuclides significantly affects the level of terrestrial radiation in a given area. Together with cosmic rays they represent the main sources of external exposure. Gamma spectrometric analysis of soil samples is an integral part of continuous long-term monitoring and evaluation of radiation.

As one of few components of the environment, ${ }^{137} \mathrm{Cs}$ is well detectable in soils until present (Palagyi et al. 2013). Modified sequential extraction analysis published by Tessier (Tessier et al. 1979; Pipiška et al. 2004; Galamboš et al. 2012) was used to study the distribution, determination of bioavailability and uptake of radionuclides by plants.

Radiocaesium is most strongly retained in clay minerals. For this radionuclide, its residual fraction is the most important (Bowen 1979; Ciuffo et al. 2003). The water-soluble and removable fractions of radiocaesium defining the intensity of vertical migration in the soil samples represent only 5\%. In the annual sediments of the Morava River and the Brno Dam, ${ }^{137} \mathrm{Cs}$ was found to a depth of $42 \mathrm{~mm}$ of the upper sediment, and to a depth of $2.9 \mathrm{~mm}$ in the lower sediment (Sedláček et al. 2013).

\section{Plant contamination}

Some plants have a high ability of ${ }^{137} \mathrm{Cs}$ uptake from the environment and thus are considered to be bioindicators (Vaaramaa et al. 2009; Rulík et al. 2014). Mosses are able to capture up to $93 \%$ of airborne radionuclides (Heinrich et al. 1989). Bilberry (Vaccinium myrtillus) belongs among boreal forest plants that are spread mainly by the vegetative way of reproduction, creating dense intertwined root systems, where one plant often occupies an area of few square metres (Nimis 1996). Even 20 years after the Chernobyl accident, ${ }^{137} \mathrm{Cs}$ may under certain conditions and in some areas increasingly penetrate bilberry fruits (Nimis 1996; Commission Recommendation 2003) which are very popular and heavily harvested forest fruits in many European countries.

In 1999-2002 the highest radioactivity contamination of ${ }^{137} \mathrm{Cs}$ measured in bilberries from the French Alps was 5-140 Bq $\mathrm{kg}^{-1}$ fresh weight (Pourcelot et al. 2003).

In the context of reports from other countries on cases of exceeding ${ }^{137} \mathrm{Cs}$ concentrations in bilberries and bilberry products in the Rapid Alert System and the European Commission recommendations (Commission Recommendation 2003) at the end of the summer of 
2005, The State Veterinary and Food Administration of the Slovak Republic carried out a targeted control of all commodities containing berries commercially distributed and sold in Slovakia. From among all of the controlled frozen bilberry samples, the highest activity $\left(535.7 \mathrm{~Bq} \cdot \mathrm{kg}^{-1}\right)$ was found in fruits originating from Romania. Sample contamination was close to the hygienic limit of $600 \mathrm{~Bq} \cdot \mathrm{kg}^{-1}$ valid for the total caesium content $\left({ }^{134} \mathrm{Cs}+{ }^{137} \mathrm{Cs}\right)$ in foodstuffs within EU countries (Council Regulation 2000). The lowest activity was found in bilberries from Belgium $\left(7.58 \mathrm{~Bq} \cdot \mathrm{kg}^{-1}\right)$. From samples of bilberry compotes, the highest activity $\left(33.3 \mathrm{~Bq} \cdot \mathrm{kg}^{-1}\right)$ was measured in a sample coming from the Czech Republic (Miššík et al. 2006).

\section{Mushroom contamination}

Fungi, as one of the most important constituents of forest ecosystem are capable of accumulating a significant amount of radionuclides including ${ }^{137} \mathrm{Cs}$ (Heinrich 1991; Škrkal et al. 2013; Guillen and Baeza 2014). It is due to their heterotrophic metabolism, significantly different from green plants, and dependence on the supply of final organic compounds (Yoshida and Muramatsu 1994).

Some species of fungi, including the edible ceps (Boletaceae family) that grow in the deciduous forests of Central Europe, are not only bioindicators of environmental contamination by radiocaesium (and heavy metals), but their consumption represents a potential hygienic and health risks (Linkov et al. 2000; Kaláč 2001; BystrzejewskaPiotrowska et al. 2003; Dvořák et al. 2006).

Radiocaesium distribution in different mushroom body parts was uneven but higher activity was determined in the mushroom caps (Heinrich 1993; Mukhopadhyay et al. 2007). The ability to accumulate radionuclides from the environment differs among different species of ceps (Kaláč 2001). This corresponds with the finding that increased accumulation of ${ }^{137} \mathrm{Cs}$ in the bay bolete (Xerocomus badius, syn. Boletus badius) is mainly due to the presence of the pigment norbadion A, present in the mushroom cap (Aumann et al. 1989). It is assumed that, as in higher plants, radiocaesium activity in fungi is associated with the growth phase, and that the total radiocaesium activity decreases with gradual growth. In terms of health, the most risky are therefore the smallest fruiting bodies, which are most commonly used for canning.

Mushroom samples collected in coniferous forests are characterized by a high content of radionuclides compared to those collected in deciduous forests (Čipáková 2004).

Findings on the radiocaesium mass activity from different areas of the Czech and Slovak Republics in 2000-2004 were published by Dvořák et al. (2006a). The highest ${ }^{137} \mathrm{Cs}$ activity of $6,263 \mathrm{~Bq} \cdot \mathrm{kg}^{-1}$ dry weight (measured by gamma spectrometry method) was found in Xerocomus badius from the Old Ransko area (Czech-Moravian Highlands). The highest ${ }^{137} \mathrm{Cs}$ concentration of $966 \mathrm{~Bq} \cdot \mathrm{kg}^{-1}$ dry weight in Slovakia was measured in Suillus luteus, in the area of Senica. For comparison, ${ }^{137} \mathrm{Cs}$ activity in the sample of mixed dried ceps (Boletaceae family) coming from the $30 \mathrm{~km}$ Chernobyl border zone, was $6,000 \mathrm{~Bq} \cdot \mathrm{kg}^{-1}$ dry weight. Results for dried mushrooms show that there is currently no ${ }^{137} \mathrm{Cs}$ activity dependency related to the distance from the place of the radioactive accident or the location altitude. These results also indicate significantly lower values of ${ }^{137} \mathrm{Cs}$ activity in the Slovak Republic compared to the Czech Republic, despite the fact that Slovakia is closer to Ukraine. Explanations should be sought in the airborne radioactive cloud movement through various parts of Europe after the Chernobyl disaster.

In the Czech Republic mainly the Czech-Moravian Highlands region was monitored, as it was impacted by radioactive clouds passing over it for three times. Slovakia was affected considerably less.

In fresh mushrooms collected in the French Alps in $1999-2002,{ }^{137} \mathrm{Cs}$ activity ranged from 273-1,165 Bq $\mathrm{kg}^{-1}$ (Pourcelot et al. 2003). 


\section{Animal contamination}

Due to the fact that Scandinavia was heavily contaminated by the Chernobyl radiocaesium fallout, considerable attention within the food chain was paid to elk (Palo et al. 2003) and reindeer meat (Skuterud et al. 2004). Similar attention was paid also to marine organisms (seafood), such as crab from the north of Ireland (Copplestone et al. 2004). In Central Europe, the animal product most contaminated from the Chernobyl accident was game meat (Sprem et al. 2013). Relatively higher activity of ${ }^{137} \mathrm{Cs}$ in wild animals is based on the mosaic pattern of the contamination area after the Chernobyl accident, in the way the wild animals searches and acquires food (especially wild boar), and in a significantly greater mobility and persistence of radiocaesium in the forest ecosystems, compared to intensively used agricultural land (Vaaramaa et al. 2009).

The Recommendation of the European Commission (2003) highlights the limit for radiocaesium activity in game meat, and calls on the Member States to act upon it in order to protect the consumers. Member states should implement steps to ensure that the limits set by the Directive no. 737/90 / EEC (2000) for marketing game meat, wild berries, mushrooms, and predatory lake fish, are respected. At the same time it recommends warning the inhabitants of affected regions of the health risks resulting from contaminated food consumption. Member States are asked to prepare a feedback on the implementation of this Directive for the European Commission and other EU Member States.

After a gradual decline of the ${ }^{137} \mathrm{Cs}$ activity in game muscles in the $1990 \mathrm{~s}$, unexpected increase of activity occurred after the floods in North-Eastern Moravia in 1997. In the meat of wild boar, the activity exceeded the hygienic limit set for the EU countries $\left(600 \mathrm{~Bq} \cdot \mathrm{kg}^{-1}\right)$, especially in the age category up to 1 year. Since 2000 , the ${ }^{137} \mathrm{Cs}$ activity has been reduced back to the level before the floods (Obzina 2002). Seasonal fluctuation of ${ }^{137} \mathrm{Cs}$ activity in the wild boar meat samples was observed in the forests on Southern Rhineland. In the examined muscle tissue the median activity was $129 \mathrm{~Bq} \cdot \mathrm{kg}^{-1}$, and the maximum reached was 5,573 Bq $\mathrm{kg}^{-1}$ (Hohmann and Huckschlag 2005). From 1998 to 2008, 656 samples from the wild boar were analysed in the district of Ravensburg (Southern Germany). The activity was variable from less than 5 up to $8,266 \mathrm{~Bq} \cdot \mathrm{kg}^{-1}$, depending on the season, weather conditions and the associated changes in dietary habits and food availability (Semizhon et al. 2009). High radioactivity concentrations (up to $10,699 \mathrm{~Bq} \cdot \mathrm{kg}^{-1}$ ) were reported in the wild boar muscles from the Šumava Region of the Czech Republic (Latini 2011). In 2012, the highest value measured was $14,252 \mathrm{~Bq} \cdot \mathrm{kg}^{-1}$ (Kouba et al. 2013). Wild boar muscle contamination is mainly due to the consumption of the underground fruiting bodies of the mushroom genus of Elaphomyces sp. (E. granulatus - deer balls, hart's truffles) (Hohmann and Huckschlag 2005; Dvořák et al. 2010). The highest ${ }^{137} \mathrm{Cs}$ specific activity of $4,743 \mathrm{~Bq} \cdot \mathrm{kg}^{-1}$ was detected in the mushroom fruiting bodies in the area of Sabrava, while the other components of the food chain of wild boar did not exceed a few tens of $\mathrm{Bq} \cdot \mathrm{kg}^{-1}$ (Dvořák et al. 2010).

\section{Possibilities of reduction of food contamination}

\section{Reduction of radiocaesium transfer to animals}

A wide range of different and effective measures were implemented to reduce the contamination of livestock by radiocaesium. Administration of potassium in the diet caused an increase in radiocaesium excretion (Mraz et al. 1958; Mraz 1959; Johnson et al. 1968), while the administration of stable caesium was not efficient (Oughton et al. 1989; Rundo 1964). Different complexes or chelating additives are used successfully, with the ability to absorb and/or to bind radionuclides forming chemical compounds not absorbed by the digestive tract but easily excreted from the body (Giese 1988; Giese 1989; Pöschl and Baláš 1999; Pöschl and Řezáč 2004). The same positive effect on 
${ }^{137} \mathrm{Cs}$ contamination reduction was observed by adding $5 \%$ bentonite into a feeding ration (Andersson et al. 1990). In ruminants grazing on mountain pastures in Norway, salt lick with $2.5 \%$ AFCF (Giese salt) was used with a positive effect (Hove et al. 1990). Capsules containing $15-20 \%$ AFCF reduced the radiocaesium concentration in meat by $50-80 \%$ (Hove 1993).

Publications on the reduction of radionuclides directly in the foodstuff are very rare, and were mainly focused on mushrooms and meat. However, a marked reduction to acceptable concentrations of radiocaesium in foodstuffs was achieved by leaching, macerating, marinating, soaking and/or boiling.

Caesium has a number of physical and chemical properties that are similar to those of potassium. In vivo, the two elements behave similarly, and they do not influence each other. Due to good water solubility, caesium is very well and relatively evenly absorbed, and distributed in the body. After the Chernobyl accident, from the total amount of radiocaesium present in different types of foodstuffs meat accounted for $50 \%$, foods of plant origin approximately $30 \%$, and milk $14 \%$ (Wagner 1988).

\section{Reduction of radiocaesium contamination in mushrooms}

For ${ }^{137} \mathrm{Cs}$ activity reduction in fungi, some preservation methods can be used. The basic form of fungi storage include drying, preservation in vinaigrette, or freezing, with drying representing the oldest preservation method. During drying, $80-90 \%$ of the mushroom water content is evaporated. Due to the relatively long half-life of radiocaesium, ${ }^{137} \mathrm{Cs}$ remains in the dry matter as a source of contamination for a long time.

Almost complete ${ }^{137} \mathrm{Cs}$ decontamination was achieved by dipping frozen or dried mushrooms in brine (Neukom and Gisler 1991). Similar results in mushrooms were achieved by using boiling in water (over $80 \%$ decontamination) and salted boiling water (Steger et al. 1987; Klan et al. 1988).

Canning of mushrooms in vinaigrette is one of the most popular preservation methods, as mushrooms treated in this way have multiple uses. Significant ${ }^{137} \mathrm{Cs}$ content reduction $(59-73 \%)$ was achieved in fungi by soaking them in vinegar brine (2\% solution of acetic acid) (Dvořák et al. 2006b). One load in the vinegar brine showed a very positive effect on ${ }^{137} \mathrm{Cs}$ activity reduction in both dried and fresh mushrooms. Nevertheless by repeating the process, mushroom consistency deteriorated, especially in mushrooms that were thawed or fresh. Dried mushrooms maintained their consistency for the whole period of the experiment.

As the decrease in ${ }^{137} \mathrm{Cs}$ activity achieved by $2 \%$ acetic acid solution treatment has an exponential character, in areas significantly affected by post-Chernobyl radiation, the vinaigrette preservation technology for mushrooms can be recommend. However, it needs to be pointed out that the vinaigrette itself must not be consumed (Dvořák et al. 2006b).

\section{Reduction of radiocaesium contamination in meat}

Elimination or at least reduction of radioactivity in the red deer (Cervus elaphus) meat can be achieved by marinating, soaking in brine or water (Jandl et al. 1989). This procedure is one of the oldest method of preserving meat, using long-term brine treatment, or using salty mixtures composed of table salt with the addition of $3 \%$ sodium nitrate or potassium. After two days, a $50 \%$ reduction of ${ }^{137} \mathrm{Cs}$ is achieved in comparison to the sample starting value. The second and third loading for additional $2+2$ days decreased radiocaesium activity to $20 \%$ and $10 \%$, respectively. It has been shown that increasing temperatures speeds up the radiocaesium release process in reindeer meat. Meat cooking was only slightly less effective in radiocaesium reduction than meat treatment in salt solutions or plain water. A $1 \%$ salty water solution was used for heat treatment (meat cooking) (Lofti et al. 1989). 
Washing meat samples under running water for $17 \mathrm{~h}$ showed a decrease of ${ }^{137} \mathrm{Cs}$ by up to $10 \%$ of the starting level (Petäjä et al. 1992).

After heat pressure treatment the mean ${ }^{137} \mathrm{Cs}$ activity in the meat was reduced by $50 \%$ (Dvořák and Kunová 2006).

To reduce meat contamination by brining, both pure $8 \%$ sodium chloride and a mixture of $8 \%$ sodium chloride and potassium nitrate were used. The brine was exchanged each $24 \mathrm{~h}$ and the process was repeated $\times 4$ for pure $8 \%$ sodium chloride and $\times 3$ for the mixture of $8 \%$ sodium chloride and potassium nitrate. Pure $8 \%$ sodium chloride brine reduced ${ }^{137} \mathrm{Cs}$ concentration by $72 \%$; the mixture of $8 \%$ sodium chloride and potassium nitrate by $77 \%$ (Dvořák et al. 2008).

Impact of using salt treatment on radiocaesium reduction was also studied in fish (Petäjä et al. 1992). The radiocaesium activity in fish meat was reduced by $50 \%$ after $4 \mathrm{~h}$ either by using 5\% saline and water, or by watering for $8 \mathrm{~h}$ (Petäjä et al. 1992).

\section{Conclusion}

Despite the fact that shortly the $30^{\text {th }}$ anniversary of the Chernobyl accident will be commemorated, we still face its dire consequences to this day. Excessive values of ${ }^{137} \mathrm{Cs}$ measured in the past years in the meat of the wild boar population in Germany and the Czech Republic represent a potential radioactive risk for humans. For this reason, radioactivity tracking as well as studying new methods of food decontamination is still highly actual.

\section{Acknowledgement}

This study was carried out in the framework of VEGA 1/0415/13.

\section{References}

Andersson I, Haekansson J, Anner K 1990: Transfer of cesium-137 from grain to muscle and internal organs of growing finishing pigs, and the effect of feeding bentonite. Swed J Agr Res 20: 43-48

Aumann DC, Clooth G, Steffan B, Steglich W 1989: Komplexierung von Caesium-137 durch die Hutfarbstoffe des Maronenröhrlings (Xerocomus badius). Angew Chem 101: 495-496

Bowen HJM 1979: Environmental Chemistry of the Elements, Academic Press, London, UK, 333 p.

Bystrzejewska-Piotrowska G, Urban P L, Steborowski R 2000: Discrimination between ${ }^{137} \mathrm{Cs}$ and ${ }^{40} \mathrm{~K}$ in the fruiting body of wild edible mushrooms. Nucleonika 48: 155-157

Ciuffo L, Velasco H, Belli M, Sansone U 2003: ${ }^{137}$ Cs soil-to-plant transfer for individual species in a semi-natural grassland. Influence of potassium soil content. J Radiat Res 44: 277-283

Commission Recommendation 2003/120/EC, On the protection and information of the public with regard to exposure resulting from the continued radioactive caesium contamination of certain wild food products as a consequence of the accident at the Chernobyl nuclear power station. Official Journal of the European Union, L47, February 21, 2003, pp. 53-55

Copplestone D, Jackson D, Hartnoll RG, Johnson M, McDonald P, Wood N 2004: Seasonal variation in activity concentrations of Tc-99 and Cs-137 in the edible meat fraction of crabs and lobsters from the central Irish Sea. J Environ Radioactiv 73: 29-48

Council Regulation 616/2000/EC, Council Regulation of $20^{\text {th }}$ March 2000 amending Regulation (EEC) No $737 / 90$ on the conditions governing imports of agricultural products originating in third countries following the accident at the Chernobyl nuclear power station. Official Journal of the European Union, L75, March 20, 2000

Csupka Š, Carach J, Petrášová M 2004: Environmental Radioactivity in Slovakia / Czechoslovakia in 1961-1975. Regional Public Health Authority, Bratislava, 226 p.

Čipáková A 2004: Cs - 137 content in mushrooms from localities in eastern Slovakia. Nucleonika 49: 25-29

Dvořák P, Kunová V, Beňová K, Ohera M 2006a: Radiocaesium in mushrooms from selected locations in the Czech Republic and the Slovak Republic. Radiat Environ Bioph 45: 145-151

Dvořák P, Kunová V, Beňová K 2006b: Exponential drop of radiocaesium activity in mushrooms due to the effect of acetic acid. Eur Food Res Technol 222: 139-143

Dvořák P, Kunová V 2006: The reduction of the activity concentration of radiocaesium in meat by heat-pressure boiling. Fol Vet 50:12-13

Dvořák P, Kunová V, Kunová J, Beňová K 2008: Radiocaesium activity reduction in boar meat by brining. Radiat Environ Bioph 47: 179-182 
Dvořák P, Snášel P, Beňová K 2010: Transfer of radiocaesium into wild boar meat. Acta Vet Brno 79: 85-91

Gadd GM 1996: Influence of microorganisms on the environmental fate of radionuclides. Endeavour 20: $150-156$

Galamboš M, Suchánek P, Rosskopfová O 2012: Sorption of anthropogenic radionuclides on natural and synthetic inorganic sorbents. J Radioanal Nucl Chem 293: 613-633

Giese WW 1988: Ammonium-ferric-cyano-ferrate (II)(AFCF) as an effective antidote against radiocaesium burdens in domestic animals and animal derived foods. Br Vet J 144: 363-369

Giese WW 1989: Countermeasures for reducing the transfer of radiocaesium to animal derived foods. Sci Total Environ 85: 317-327

Guillen J, Baeza A 2014: Radioactivity in mushrooms: A health hazard? Food Chem 154: 14-25

Heinrich G, Muller HJ, Oswald K, Gries A 1989: Natural and artificial radionuclides in selected Styrian soils and plants before and after reactor accident in Chernobyl. Biochem Physiol Pfl 185: 55-67

Heinrich G 1991: Uptake and transfer factors of ${ }^{137} \mathrm{Cs}$ by mushrooms. Radiat Environ Bioph 31: $39-49$

Hohmann U, Huckschlag D 2005: Investigations on the radicaesium of wild boar (Sus scrofa) meat in Rhineland - Palatine: a stomach content analysis. Eur J Wild Res 51: 263-270

Hove K, Hansen HS, Strand P 1990: Experience with the use of caesium binders to reduce radiocaesium contamination of grazing animals. In: Flitton S, Katz EW et al.: Environmental Contamination Following a Major Nuclear Accident. International Atomic Energy Agency, Vienna, IAEA-SM-306/36, pp. 181-189

Hove K 1993: Chemical methods for reduction of the transfer of radionuclides to farm-animals in semi-natural environments. Sci Total Environ 137: 235-248

Högberg L 2013: Root causes and impacts of severe accidents at large nuclear power plants. Ambio 42: 267-284

Jandl J, Novosad J, Francová H, Procházka H 1989: Cesium removal from the deer meat. Vet Med-Czech 34: $485-490$

Johnson J E, Garner D, Ward GM 1968: Influence of dietary potassium, rubidium or sodium on retention time of radiocaesium in rats. Proceedings of the Society for Experimental Biology and Medicine 127: 857-861

Kalač P 2001: A review of edible mushroom radioactivity. Food Chem 75: 29-35

Klan J, Randa Z, Benada J, Horyna J 1988: Investigation of non-radioactive Rb, S and radiocaesium in higher fungi (in Czech). Česká mykologie 42: 158-169

Koprda V 1986: Internal contamination by radioactive substances. Science - Slovak Academy of Sciences, Bratislava, 365 p.

Kouba F, Cipínová E, Drápal J, Hanzal V, Malena M, Vernerová K 2013: The radioactivity monitoring of wild boars in the South Bohemian Region (in Czech). Maso 3: 151-154

Krolak E, Kwapulinski J, Fischer A 2010: (137)Cs and (40)K isotopes in forest and wasteland soils in a selected region of eastern Poland 20 years after the Chernobyl accident. Radiat Environ Bioph 49: 229-237

Latini T 2011: The presence of radioactivity in the feral pigs (in Czech). Maso 5: 24-26

Linkov I, Yoshida S, Steiner M 2000: Fungi contaminated by radionuclides. Critical review of approaches to modelling. Proceedings of the $10^{\text {th }}$ International Congress of the International Radiation Protection Association, Hiroshima, pp. 1-10

Lofti M, Nataro M, Piermattei S, Tommasino L, Azimi-Garakani D 1989: Radiocaesium contents of meat in Italy after the Chernobyl accident and their changes during the cooking process. J Environ Radioactiv 12: 179-183

Miššík J, Puskeiler L, Mikláš P 2006: Penetration of ${ }^{137} \mathrm{Cs}$ into the human body after consumption of naturally collected or commercially sold bilberries. Third Conference of Radiobiology, UVM Kosice, pp. 221-226

Mraz FR, Johnson AM, Homer P 1958: Metabolism of caesium and potassium in swine as indicated by caesium-134 and potassium-42. J Nutr 64: 541-548

Mraz FR 1959: Influence of dietary potassium and sodium on caesium-134 and potassium - 42 excretion in sheep. J Nutr 68: 655-662

Mukhopadhyay B, Nag M, Laskar S, Lahiri S 2007: Accumulation of radiocaesium Pleurotus citrinopileatus species of edible mushroom. J Radioanal Nucl Ch 273: 415-418

Neukom HP, Gisler E 1991: Extraction of radioactive caesium from mushrooms with xerocomus-badius as an example. Lebensm Wiss Technol 24: 442-444

Nimis PL 1996: Radiocaesium in plants of forest ecosystems. Studia Geobotanica 15: 3-49

Obzina J 2002: Presence of radiocaesium in the game meat from the districts Sumperk and Jeseník between 1992-2002 (in Czech). PhD thesis, University of Veterinary Medicine and Pharmacy Brno, 35 p.

Oughton DH, Salbu B, Hove K, Day JP 1989: The use stable caesium to reduce radiocaesium transfer to meat. In: Gunnerod TB, Garma TH (eds): The Research Programme of Radioactive Fallout. Agricultural University of Norway, As, Norway, pp. 117-127

Palágyi Š, Štamberg K, Vodičková H, Hercík M 2013: Sorption of ${ }^{125} \mathrm{I}^{-},{ }^{137} \mathrm{Cs}^{+},{ }^{85} \mathrm{Sr}^{2+}$ and ${ }^{152,}{ }^{154} \mathrm{Eu}^{3+}$ during their transport in undisturbed vertical and horizontal soil cores under dynamic flow conditions. J Radioanal Nucl Ch 295: $1447-1458$

Palo RT, White N, Danell K 2003: Spatial and temporal variations of Cs-137 in moose Alces alces and transfer to man in northern Sweden. Wild Biol 9: 207-212

Pedersen CS, Nyb S, Varskog P 1998: Seasonal variation in radiocaesium concentration in willow ptarmigan and rock ptarmigan in Central Norway after the Chernobyl fallout. J Environ Radioactiv 41: 65-81

Petäjä E, Rantavaara A, Paakola O, Puolanne E 1992: Reduction of radioactive caesium in meat and fish by soaking. J Environ Radioactiv 16: 273-285 
Pipíška M, Lesný J, Hornik M, Augustin J 2004: Plant uptake of radiocaesium from contaminated soil. Nucleonika 49: 9-11

Pourcelot L, Renaud P, Louvat D, Gurriaran R, Richon P 2003: Influence of hot spots on cesium-137 contamination of an alpine food chain and doses associated with it. ERS 2: 112-120

Pöschl M, Baláš J 1999: Reduction of radiocaesium transfer to broiler chicken meat by a clinoptilolite modified with hexacyanoferrate. Radiat Environ Bioph 38: 117-124

Pöschl M, Řezáč P 2004: Reduction of radiocaesium transfer to broiler chicken meat by the hexacyanoferratecellulose binder "Bifezh". Radiat Environ Bioph 43: 277-284

Rulík P, Pilátová H, Suchara I, Sucharová J 2014: Long-term behavior of Cs-137 in spruce bark in coniferous forests in the Czech Republic. Environ Pollut 184: 511-514

Rundo J 1964: A survey of the metabolism of caesium in man. Br J Radiol 37:108-127

Sedláček J, Bábek O, Grygar TM 2013: Trends and evolution of contamination in a well-dated water reservoir sedimentary archive: The Brno Dam, Moravia, Czech Republic. Environ Earth Sci 69: 2581-2593

Semizhon T, Putyrskaya V, Zibold G, Klemt E 2009: Time-dependency of the ${ }^{137} \mathrm{Cs}$ contamination of wild boar from a region in Southern Germany in the years 1998 to 2008. J Environ Radioactiv 100: 988-992

Schimmack W, Bunzl K 1996: Mobility of Chernobyl-derived radiocaesium in the soil. Proceedings of the International Symposium on Radioecology, Vienna. In: Mitt Österr Bodenkdl Ges 53: 11-18

Skuterud L, Pederson O, Staaland H, Roed KH, Salbu B, Liken A, Hove K 2004: Absorption, retention and tissue distribution of radiocaesium in reindeer: effects of diet and radiocaesium source. Radiat Environ Bioph 43: 293-301

Sprem N, Babic I, Barisic D, Barisic D 2013: Concentration of ${ }^{137} \mathrm{Cs}$ and ${ }^{40} \mathrm{~K}$ in meat of omnivore and herbivore game species in mountain forest ecosystems of Gorski Kotar, Croatia. J Radioanal Nucl Ch 298: 513-517

Steger U, Burger A, Ziegler W, Wallnöfer PR 1987: Distribution of Cs-134 and Cs-137 in foodstuffs processed in the kitchen. Dtsch Lebensmitt Rundsch 83: 85-88

Škrkal J, Rulik P, Fantinova K, Burianová J, Helebrant J 2013: Long-term Cs-137 activity monitoring of mushrooms in forest ecosystems of the Czech Republic. Radiat Prot Dosimetr 157: 579-584

Tessier A, Campbell PGC, Bisson M 1979: Sequential extraction procedure for the speciation of particulate trace metals. Anal Chem 51: 840-855

Tomioka N, Uchiyama H, Yagi O 1992: Isolation and characterization of cesium - accumulation bacteria. Appl Environ Microbiol 58: 1019-1023

UNSCEAR 1988: Sources, Effects and Risks of Ionizing Radiation. UN report, New York.

Vaaramaa K, Solatie D, Aro L 2009: Distribution of Pb-210 and Po-210 concentrations in wild berries and mushrooms in boreal forest ecosystems. Sci Total Environ 408: 84-91

Wagner H 1988: Transfer of radioactive substances from feed into the meat of slaughter animals Fleischwirtschaft 68: $656-664$

Yoshida S, Muramatsu Y 1994: Accumulation of radiocaesium in basidiomycetes collected from Japanese forests. Sci Total Environ 157: 197-205 